\title{
Effect of Feed Withdrawal Stress on Reproductive Tissue, Sex Steroids and mRNA Expression of IGF-1, Survivin, Caspase 2 and HSP 70 Gene in the Ovarian Follicles of Japanese Quail
}

\author{
N. Shit, K.V.H. Sastry, G. Singh¹, R.P. Singh, J. Mohan
}

10.18805/IJAR.B-4214

\begin{abstract}
Background: Japanese quail, similar to domestic chicken, is equally sensitive and susceptible to stress but limited literatures are available so far. Therefore, this study was aimed to investigate the effect of feed withdrawal stress on the changes in reproductive tissues, steroid hormones and gene expression in Japanese quail.

Methods: Forty two quail hens (10weeks) were individually caged and subjected to feed withdrawal for a period of 10 days without water restriction. Six birds each were sacrificed on $0,1,2,4,6,8$ and 10 day. The reduction in oviduct weight and serum concentration of steroid hormones was evaluated. The quantitative expression of IGF-1, Caspase-2, Survivin and HSP-70 genes were performed in ovarian follicles using real-time PCR.

Result: No hierarchial follicles were detected after day 6 . The ovary and oviduct weight was significantly reduced on day 2 and 4 respectively. The serum estrogen and progesterone were declined significantly when corticosterone was increased from day 1 . The IGF-1 gene expression was significantly $(\mathrm{P}<0.05)$ down regulated in yellow and atretic follicles. The gene expression of Survivin and caspase-2 was up-regulated in $\mathrm{F}_{3}$ follicle. It concludes feed withdrawal brings noticeable change in reproductive tissues, steroid hormones and associated gene expression in Japanese quail.
\end{abstract}

Key words: Gene expression, Hormones, Japanese quail, Ovarian follicle, Stress.

\section{INTRODUCTION}

Stress leads to the activation of the hypothalamo-pituitaryadrenal (HPA) axis which accelerates glucocorticoid secretion (Brandt et al., 2007) and Similar to domestic fowl, the gonadal regression in male Japanese quail evidently reported a direct effect of food deprivation on reproductive organs (Kobayashi et al., 2004). Further, such events accentuate metabolic changes like hepatic glycogenolysis, protein catabolism andgluconeogensis to mobilize energy reserves to assist an individual toevade the stressors (Razdan, 2003). The regression of ovary and oviduct and follicular atresia is well evident in White Leghorn hens during moulting by feed withdrawal (Agarwal et al., 2013). The increased expression of cytokines in the ovary causes significant reduction of estrogen and progesterone and subsequently increased serum corticosterone in single comb White Leghorn hens subjected to feed withdrawal (Sundaresan et al., 2007). Interestingly, Japanese quail farming now-a-days is gaining popularity as potential alternative to chicken dominated poultry industry because of its small size, less floor space requirement, short generation interval, rapid growth, early sexual maturity and disease resistance (Amrutkar et al., 2013). Their maturation is directly associated with body weight gain and attained highest body weight by $9^{\text {th }}$ weeks of age (Shit et al., 2014).

However, this smallest domesticated avian species is also highly sensitive to stress and encounters negative impact on reproductive functions (Shit et al., 2014). Shit
Physiology and Reproduction Division, Central Avian Research Institute, Izatnagar-243 122, Uttar Pradesh, India.

${ }^{1}$ Physiology and Climatology Division, Indian Veterinary Research Institute, Izatnagar-243 122, Uttar Pradesh, India.

Corresponding Author: N. Shit, Animal Science, RRS-TZ, Uttar Banga Krishi Viswavidyalaya, Cooch Behar-736 165, West Bengal, India. Email: drnonigopal@gmail.com

How to cite this article: Shit, N., Sastry, K.V.H., Singh, G., Singh, R.P. and Mohan, J. (2021). Effect of Feed Withdrawal Stress on Reproductive Tissue, Sex Steroids and mRNA Expression of IGF1, Survivin, Caspase 2 and HSP 70 Gene in the Ovarian Follicles of Japanese Quail. Indian Journal of Animal Research. DOI: 10.18805/IJAR.B-4214.

Submitted: 10-06-2020 Accepted: 15-12-2020 Online: 02-02-2021

et al. (2016) concluded that the ovary and oviduct weight in Japanese quail were reduced by $82.60 \%$ and $53.54 \%$ respectively during immobilization stress. The regression of the reproductive tract induced by feed withdrawal is a non-inflammatory event mediated by apoptosis (Sundaresan et al., 2007). Stress associated changes in the expression of IGF-1 gene in ovarian follicles confirms that it plays crucial role in avian reproduction as they hasten dose dependent gonadal steroid hormone synthesis, cell proliferation, selection and inhibition of follicular apoptosis by inhibiting oligonucleosome formation (Lovell et al.,2002, Tosca et al., 2008). Survivin gene controls cell proliferation and cell death 
during cell division (Wheatley and McNeish, 2005). It is evident that the over expression of survivin gene is only reported in embryonic and foetal tissues though it remains undetected in many normal adult tissues (Ambrosini et al., 1997). The relative expression of IGF-1 and survivin gene in the hierarchial follicles of Japanese quail is changed in reverse manner during evaluation of the immobilization stress (Shit et al., 2014). Caspases-1 and -2 are differentially up regulated in the ovary of the single comb White Leghorn hens subjected to feed withdrawal (Anish et al., 2008). The cell with increased Heat Shock Protein (HSP) exhibits better survival against the additional stress hence they are often called as stress markers (Figueiredo et al., 2007). The expression pattern of HSP-70 gene represented an inconsistent variation in the hierarchial follicles of Japanese quail (Shit et al., 2014). Though, feed withdrawal stress induced physiological and cellular change in domestic chicken is well established but scanty literatures are available so far in Japanese quail.

In view of the above facts, the present study aims to investigate the effect of feed withdrawal as stress factor on the reproductive tissues and to correlate the expression profile of IGF-1, survivin, caspase-2 and HSP-70 genes with the serum level of sex steroids in Japanese quail.

\section{MATERIALS AND METHODS}

The code of behaviours for the care and use of animals considered for this study were in accordance with the rules of the 'Animal Ethics Monitoring Committee of the Central Avian Research Institute, Izatnagar, Uttar Pradesh.

\section{Experimental birds}

The experiment was conducted in the Department of Physiology and Reproduction, Central Avian Research Institute, Izatnagar, Uttar Pradesh, India. Forty two healthy Japanese quail hens at 10 weeks of age from the same hatch were randomly selected from the institutional quail breeding farm. Following uniform husbandry conditions, birds were housed in individual cages $\left(20 \times 20 \times 20 \mathrm{~cm}^{3}\right)$ with $14: 10 \mathrm{~h}$ photo-schedule. Stress was induced following complete feed withdrawal (FW) method as described by Bell (2003) for a period of 10 days. Drinking water was ad-libitum throughout the study. Six birds each were sacrificed by cervical dislocation on days $0,1,2,4,6,8$ and 10 when day 0 served as the untreated control.

\section{Samples collection}

Ovary with largest follicles and oviduct were aseptically dissected out and weighted up to two decimal points. Serum was extracted following standard protocols (Melissa et al., 2009) and stored at $-20^{\circ} \mathrm{C}$ until use for the biochemical analysis. The hierarchial follicles (HFs) and atretic follicles (AFs) were separated carefully and placed immediately on ice. Follicles were weighed in order to identify the largest preovulatory follicle $\left(F_{1}\right)$ and classify their position and numbers for subsequent follicles. Both HFs and AFs were cut open transversely along the stigma to drain the yolk material. The follicular membranes were rinsedsufficiently with ice-cold sterile normal saline $(0.9 \%)$ tillthere was no adhering of yolk material. The tissue samples from both HFs and AFs after overnight incubation $\left(4^{\circ} \mathrm{C}\right)$ in the RNA stabilization solution (RNAlater, Ambion Inc., USA), were stored at $-80^{\circ} \mathrm{C}$ for $1-2$ weeks as per the manufacturer's instructions, till the RNA isolation was performed.

\section{RNA isolation and reverse transcription}

The total RNA was extracted from individual $\mathrm{HFs}\left(\mathrm{F}_{1}, \mathrm{~F}_{2}\right.$ and $\mathrm{F}_{3}$ ) and AFs using Trizol reagent (Invitrogen, Carlsbad, CA, USA) as per the manufacturer's instructions. The concentration and purity of RNA preparations were determined at $A_{260}$ versus $A_{280}$ by Nano-Drop system (Thermo 2000 ) and the purity was confirmed upon the ratio $\leq 2.0$ for all the samples. Each RNA sample $(5 \mathrm{mg})$ was treated with $5 \mathrm{U}$ of RNase-free DNase (Biogene, Cambridge, UK) at $37^{\circ} \mathrm{C}$ for $1 \mathrm{~h}$ to be free from the contamination of genomic DNA and subsequently inactivated by incubation at $65^{\circ} \mathrm{C}$ for $10 \mathrm{~min}$. With suitable negative and positive control, DNase-treated total RNA sample (5mg) was reverse transcribed using 'RevertAid First strand cDNA synthesis kit' (MBI Fermentas, Hanover, MD, USA) according to the manufacturer's instructions. The resultant $\mathrm{CDNA}$ was stored at $-20^{\circ} \mathrm{C}$ till used.

\section{Quantification of IGF-1, Caspase 2, Survivin and HSP} 70 by RT-qPCR

The real-time PCR was performed to quantify the transcripts of the IGF-1, Caspase 2, Survivin and HSP 70 gene using

Table 1: Oligo-nucleotide primer sequences used in the real-time polymerase chain reaction (RT-PCR) in ovarian follicles $\left(F_{1}, F_{2}, F_{3}\right.$ and atretic follicle) of Japanese quail hens.

\begin{tabular}{|c|c|c|c|c|}
\hline Gene & Primer sequences & $\begin{array}{l}\text { Annealing Temp. } \\
\qquad\left({ }^{\circ} \mathrm{C}\right)\end{array}$ & $\begin{array}{l}\text { Product Size } \\
\text { (bp) }\end{array}$ & $\begin{array}{c}\text { Reference/Accession } \\
\text { No }\end{array}$ \\
\hline \multirow[t]{2}{*}{ IGF-1 } & F-5' TGTACTGTGCTCCAATAAAGC & 58 & 127 & Guernec et al., 2003 \\
\hline & R-5' CTGTTTCCTGTGTTCсстCTACTTG & & & \\
\hline \multirow[t]{2}{*}{ Survivin } & F-5' TCGAAGATGTAGCCAAGG & 56 & 98 & HM588003 \\
\hline & R-5' CAGCGTGGCAGTGTC & & & \\
\hline \multirow[t]{2}{*}{ Caspase-2 } & F-5' TTGATTGTGGAACATTCTTTGG & 56 & 163 & HM587999 \\
\hline & R-5' CACTGCTGAAATGGATATTGC & & & \\
\hline \multirow[t]{2}{*}{ HSP-70 } & F-5' GGCACCATCACTGGGCTT & 56 & 74 & HM587997 \\
\hline & R-5' TCCAAGCCATAGGCAATAGCA & & & \\
\hline \multirow[t]{2}{*}{ Beta-actin } & F-5' GGAAGTTACTCGCCTCTG & 58 & 114 & GU230784 \\
\hline & R-5' AAAGACACTTGTTGGGTTAC & & & \\
\hline
\end{tabular}


IQ5 Cycler system (Bio-Rad, Hercules, CA, USA). Based on the suitability of the SYBR chemistry, specific primer pairs including reference gene (Beta-actin) were designed using Beacon designer software (Premier Biosoft International, Palo Alto, CA, USA) and commercially synthesized (Operon Biotechnologies, Cologne, Germany)for the quantification study. The recombinant plasmids (InsTD Aclone; MBI Fermentas) for target genes including Beta-actin were generated and confirmed by sequencing. Recombinant plasmids with an insert for target genes were used as a positive control and construction of slope. The amplification was carried out in $20 \mathrm{ml}$ volume containing qPCR master mix with SYBR Green 1 dye Fluorescein passive reference dye (DyNAmoTM HS; Finnzymes, Woburn, MA, USA), HotStart Taq DNA polymerase and dNTPs with dUTP in optimized buffer components (New England Biolabs, Ipswich, MA, USA), a $0.2-\mu \mathrm{M}$ concentration of 32 and 52 gene-specific primer (Table 1) and $1 \mu$ l of cDNA template. PCR cycling conditions for 40 cycles were as follows: initial denaturation of $95^{\circ} \mathrm{C}$ for $15 \mathrm{~min}$, subsequent denaturation at $95^{\circ} \mathrm{C}$ for $30 \mathrm{~s}$; gene specific annealing temperature for $30 \mathrm{~s}$ and extension $72^{\circ} \mathrm{C}$ for $30 \mathrm{~s}$. For each sample, a dissociation curve was generated after completion of amplification and results were expressed in terms of the threshold cycle value $\left(C_{t}\right)$, the cycle at which the change in the reporter dye (DRn) passes the significance threshold.

\section{Estimation of serum hormones}

The concentration of sex steroids (estradiol and progesterone) and corticosterone were estimated using radio immunoassay (Immunotech, France) and enzyme immunoassay (United Biotech Inc.) kits respectively following manufacturer'sguideline. The intra assay is expressed by intra assay coefficient of variation (CV) to monitor the deviation within the same assay. Each sample is measured several times and then \%CV is calculated for each sample by dividing the standard deviation of a set of measurements by the set mean and multiplying by 100 . Finally, the average of the individual CVs is denoted as intra assay $\mathrm{CV}$. The inter assay variation describes the variation of results obtained from repeated experiments and expressed by inter assay coefficient of variation to monitor the precision of results between different assays.

\section{Statistical analysis}

Data obtained during the course of the present study, were analyzed using two-way ANOVA. Graph pad prism software version 4.00 (Graph pad, USA) was used to analyses the data obtained from sex steroid hormones. The relative expression of the genes of interest was examined according to Pfaffl et al. (2002).

\section{RESULTS AND DISCUSSION Gross morphology}

The mean ovary and oviduct weight reduced significantly $(P<0.05)$ during stress in Japanese quail (Fig 1). The significant reduction of the ovary and oviduct weight was recorded on day 2 and 4 respectively and reached highest by $93 \%$ and $80.5 \%$ on day 10 compared to the value on day 0 . However, the reduction in weight was more severe in the ovary compare to the oviduct. Substantial reduction in the weight of the reproductive organs ensured a high level of gross reproductive regression in quail hens. Berry (2003)

Table 2: Correlation among the six characters considered in the present study.

\begin{tabular}{|c|c|c|c|c|c|c|}
\hline & Ovary weight & Oviduct weight & Yellow follicles & Estrogen & Progesterone & Corticosterone \\
\hline Ovary weight & 1 & & & & & \\
\hline Oviduct weight & $0.952489^{* *}$ & 1 & & & & \\
\hline Yellow follicle & $0.973846^{* *}$ & $0.897698^{*}$ & 1 & & & \\
\hline Estrogen & $0.974526^{* *}$ & $0.88336^{*}$ & $0.992469^{* *}$ & 1 & & \\
\hline Progesterone & $0.986985^{* *}$ & $0.944059^{* *}$ & $0.982075^{* *}$ & $0.974588^{* *}$ & 1 & \\
\hline Corticosterone & -0.39316 & -0.27429 & -0.41979 & -0.4394 & -0.28742 & 1 \\
\hline
\end{tabular}

*Significant at $\mathrm{P}<0.05 ;{ }^{*}$ Significant at $\mathrm{P}<0.01$.

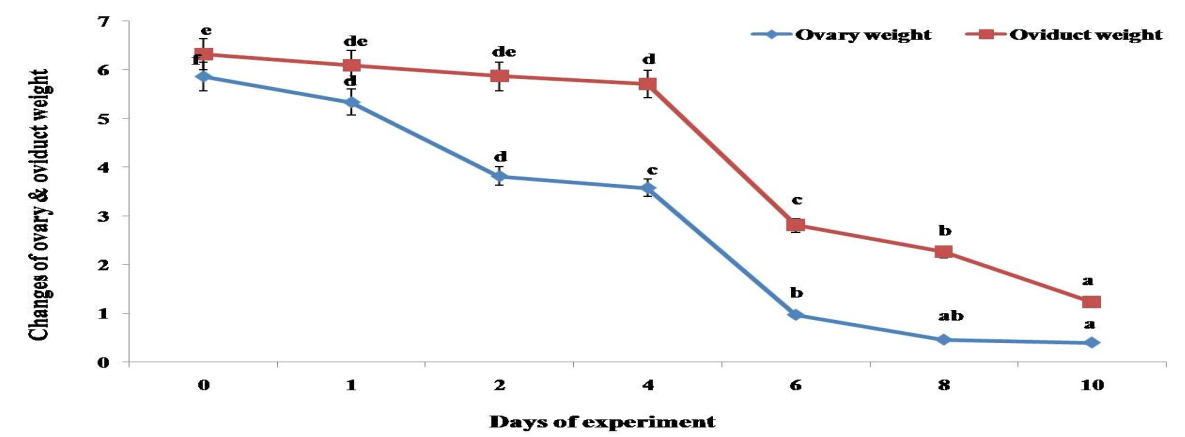

Fig 1: Percent reduction in the weights of ovary and oviduct of the Japanese quail. Graphics represent the mean weights of organs at different days of treatment (mean $\pm \mathrm{SEM}, \mathrm{N}=6$ ). Different superscripts indicate a significant difference $(p<0.05)$. 
argued that lack of gonadotropic support from the pituitary during moulting by feed withdrawal in White leghorn hens has been shown to cause atresia and resorption of yolk material and ovarian regression. The present observation could be due to low level gonadotropic support during feed withdrawal as reported in the domestic chickens. Similar to domestic chicken, the gonadal regression in male Japanese quail has been reported as a result of food deprivation on reproductive organs (Kobayashi et al., 2004). We are in agreement to the findings of Anish et al. (2008) who concluded that moulting by feed withdrawal leads to a significant reduction in reproductive organs weight of White leghorn hens.

The present observation revealed an abrupt decrease in the number of hierarchial follicles after day 2 and significant $(P<0.05)$ increase of atretic follicles subject to feed withdrawal stress (Fig 2). There were no hierarchial follicles detected after day 6 though atretic follicles were evident as early as day 2 of the experiment. A significant $(P<0.05)$ positive correlation was observed between the oviduct weight and the number of yellow follicles (Table 2).
Similar to the oviduct, we presume that owing to the lack of gonadotropic support from the pituitary, hierarchial follicles undergo into atresia. It is suggested that the small ovarian follicles are more susceptible to atresia during stress (Moudgal et al., 1991). Epinephrine secreted in response to stress induces follicle atresia in vitro and in vivo in hens (Moudgal et al., 1990). It is reported that induction of immobilization stress leads to noticeable follicular regression in Japanese quail (Shit et al., 2016).

\section{Sex steroids and corticosterone}

The mean concentrations of serum estrogen $(\mathrm{pg} / \mathrm{ml})$ and progesterone $(\mathrm{ng} / \mathrm{ml})$ were declined significantly $(P<0.05)$ on day 2 onwards, till the end of the study (Fig $3 A$ and $B$ ). However, the concentration goes below threshold value after $6^{\text {th }}$ day due to of severe reduction of the hormones. This result is found similar to Sundaresan et al. (2007) and Anish et al. (2008) who found down regulation of estrogen and progesterone in the single comb White Leghorn hens. It is suggested that the under nutrition state inhibits gonadotrophin secretion (Robinson et al., 1999). Stress

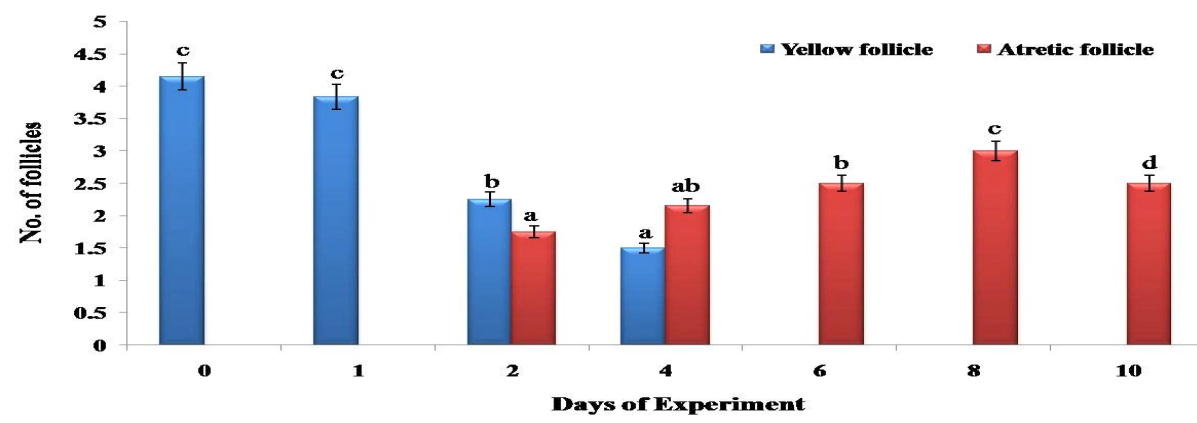

Fig 2: Graphics represent the number of yellow and atretic follicles at different days of treatment (mean $\pm S E ; N=6$ ). Different superscripts indicate a significant difference $(p<0.05)$

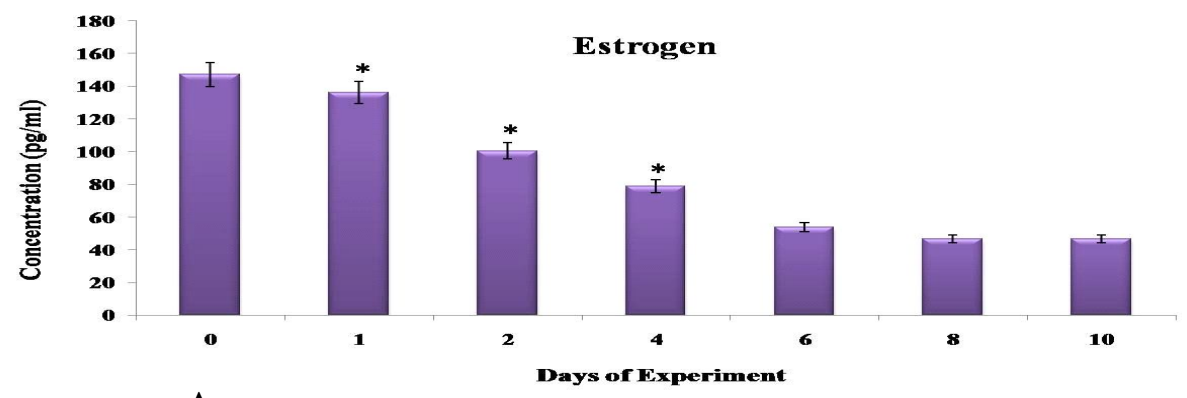

A

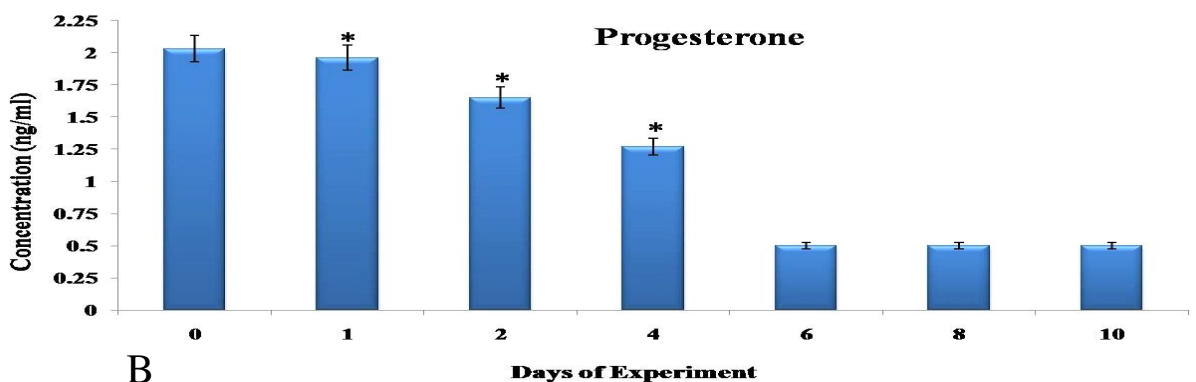

Fig 3: The serum concentrations of estrogen $(3 A)$ and progesterone $(3 B)$ in Japanese quail during stress (mean $\pm S E ; N=6)$. * indicates significant difference $(P<0.05)$ 
induced inhibition of $\mathrm{GnRH}$ pulsation affects gonadotrophin secretion from the pituitary and may be the cause of declining sex steroid concentration (Anish et al., 2008). Cytokines may be involved in declining serum estrogen and progesterone concentration in Japanese quail as reported in White leghorn hens (Sundareson et al., 2007).

The corticosterone level $(\mathrm{ng} / \mathrm{ml})$ was increased significantly $(\mathrm{P}<0.05)$ and became highest on day 2 (4.86 \pm 0.53$)$, however, the concentration was recorded then inconsistent throughout the study period (Fig 4). A significant $(P<0.01)$ negative correlation was recorded between the serum corticosterone and ovarian tissue regression (Table 2). Cockrem et al. (2004) described that corticosterone increased during stress and extends adjustment to stressors by affecting locomotion, feed intake, fluid balance and energy mobilization. The present observation is in agreement to Harvey et al. (1984) who suggested that food deprivation rapidly increases the plasma corticosterone from baseline in laying hens. Similar findings were also reported during stress in turkey (El Halawani et al., 1973), pigeons (Pilo et al., 1985) and Japanese quail (Shit et al., 2016). Stress induced activation of HPA axis and subsequent release of $\mathrm{ACTH}$ and other pro-opiomelanocortin (POMC) derived peptides i.e. â-endorphin could be the cause of higher level of corticosterone (Brandt et al., 2007).

\section{Gene expression study}

The mRNA expression of IGF-1, Survivne, Caspase 2 and HSP 70 gene was carried out in the yellow follicles $\left(F_{1}, F_{2}\right.$ and $F_{3}$ ) till day 4 . However, the gene expression study was performed in atretic follicles thereafter as yellow follicles were no longer evident.

The insulin-like growth factors (IGFs) maintain growth and differentiation of most cell types through endocrine, autocrine and paracrine control. They play crucial role in avian reproduction as they hasten dose dependent gonadal steroid hormone synthesis, cell proliferation, selection and inhibition of follicular apoptosis by inhibiting oligonucleosome formation (Johnson et al., 2001). During stress we noticed a significant $(P<0.05)$ down regulation in the fold expression of IFG-1 in both yellow and atretic follicles (Fig 5). The sensitivity to the stress stimuli was found greater for the largest follicle and the relative change was remarkable in the atretic follicles compared to the hierarchial follicles. Interestingly, both IGF-1 and IGF-2 exerts their action after binding to the same receptor IGF-R (type-1) in avian species. Stress induced decrease in the secretion of ovarian growth factors (IGFs) hastens oligonucleosome formation which initiates apoptosis in the ovarian tissues. Evidently, the mRNA and protein encoding for the IGFs receptor are expressed in immature ovary (Heck et al., 2003), granulosa and theca cells of the developing follicles (Tosca et al., 2008). The present finding is in agreement to Shit et al. (2014) who reported a significant down regulation of IGF-1 gene during immobilization stress. However, the molecular mechanism associated with IGF-1gene expression during feed withdrawal in Japanese quail is still unclear.

The current study revealed a significant $(P<0.05)$ upregulation in the fold expression of survivin gene (Fig 6 ). The $F_{2}$ yellow follicle revealed greater magnitude of
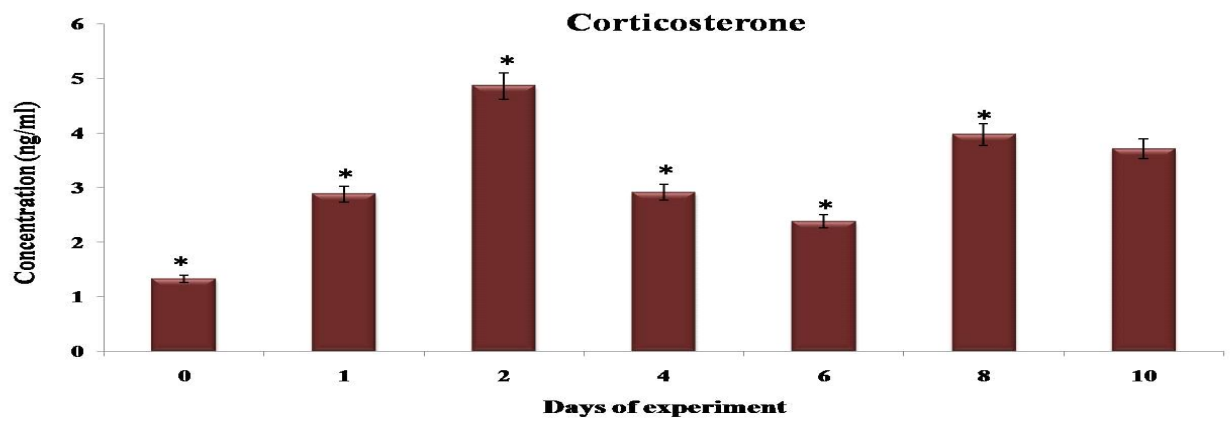

Fig 4: The serum concentrations of corticosterone in Japanese quail during stress (mean $\pm S E ; N=6$ ). * indicates significant difference $(P<0.05)$.

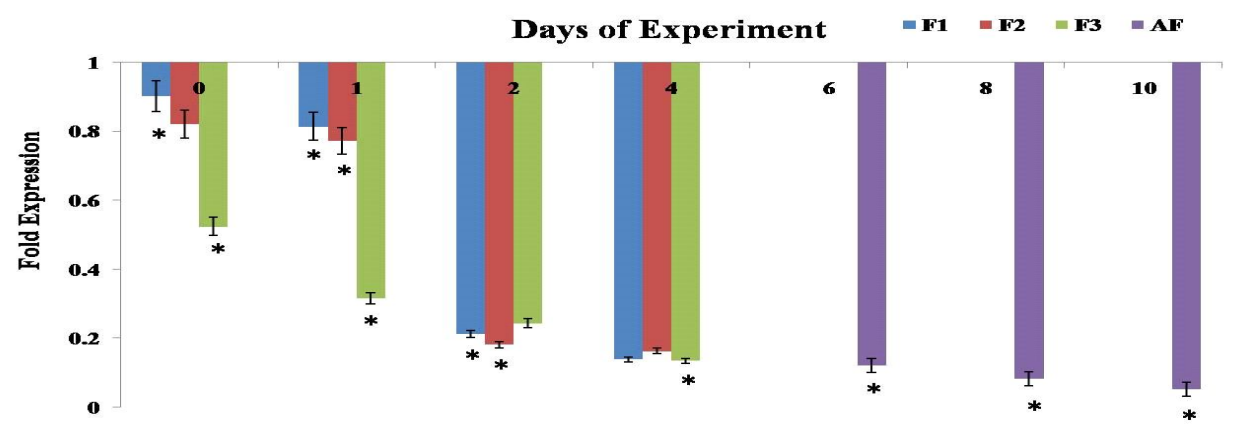

Fig 5: The mRNA expression profile of IGF-1 gene in hierarchial $\left(F_{1}, F_{2}\right.$ and $\left.F_{3}\right)$ and atretic follicle (AF) of Japanese quail under stress (mean $\pm \mathrm{SEM}, \mathrm{N}=6$ ). ${ }^{*}$ Significant at $P<0.05$. 
expression and reached its peak on day 4 of the experiment. The relative gene expression was evidently down regulated in the atretic follicles in advance to the course of study. Survivin, member of IAPs proteins, has been proposed to control cell proliferation and death (Wheatley and McNeish, 2005) and over expression is reported in embryonic and fetal tissues though detected in many normal adult tissues (Ambrosini et al., 1997). Additionally, it has been found to inhibit apoptosis either by inhibiting the cytochrome-c induced proteolytic events in the cytoplasm or by directly interfering the activities of terminal effector cell death protease i.e. caspases-3, -7 and -9 (Tamm et al., 1998; Shin et al., 2001). According to Johnson and Howerth (2004), survivin regulating $\mathrm{F}_{2}$ and $\mathrm{F}_{3}$ follicles may be mitotically more active and are under regular cell cycle (G2/M phase) and this could be correlated with the present observation. No conclusive evidence is available so far, further study is required for clarification.

In the present experiment, we observed significant $(\mathrm{P}<0.05)$ up-regulation of caspase-2 gene expression in both yellow and atretic follicles (Fig 7). The relative fold expression level was more in the largest yellow follicle $\left(F_{3}\right)$ compared to the rest $F_{2}$ and $F_{3}$ follicle. However, the magnitude of expression reached to the highest on $4^{\text {th }}$ day of the study. Caspase-2 is a nuclear resident protein and it can trigger apoptosis by release of mitochondrial cytochrome $c$ and other apoptogenic factors into the cell cytoplasm (Paroni et al., 2001; Guo et al., 2002). Evidently, stress induced intracellular nitric oxide (NO) accumulation proportionately accelerates the activation of caspase cascade which directly leads to reproductive tissue regression via apoptosis in mammals (Skarzynski et al., 2005). Caspase-2 is known for its pro-apoptotic and anti-apoptotic activities depending on the tissue where it is produced. However, a similar trend of up-regulation was recorded in the ovary and oviductal tissues (Anish et al., 2008) and in the post ovulatory follicles (Sundaresan et al., 2008) in fasted White Leghorn hens. The mechanism beneath the stress induced caspases associated reproductive tissue regression in Japanese quail is yet be explored.

The cells with increased level of Heat Shock Proteins (HSP) exhibit tolerance against the additional stress hence they are often called as stress markers (Figueiredo et al., 2007). Although the mechanism by which HSPs protect cells is known but their expression can be modulated by cell signal transducers, such as changes in intracellular pH, cyclic AMP, $\mathrm{Ca}^{2+}, \mathrm{Na}^{+}$, inositol trisphosphate, protein kinase $\mathrm{C}$ and protein phosphatase (Kiang and Tsokos, 1998). The amplified fragment sequence of quail HSP-70 is having $98 \%$ homology with the chicken and $99 \%$ to the helmeted Guinea fowl (Gaviol et al., 2008). The HSP-70 gene expression did not show any noticeable change and varied inconsistently in ovarian follicles throughout the study (Fig 8). This result is in agreement to Shit et al. (2014) who concluded an inconsistent variation in HSP-70 gene expression in Japanese quail during immobilization stress. It is demonstrated that heat shock proteins (HSPs) expressed at high level only when cells are exposed to high or low temperature or other stressors. It is also reported that heavy body weight line Japanese quail is inherently more capable

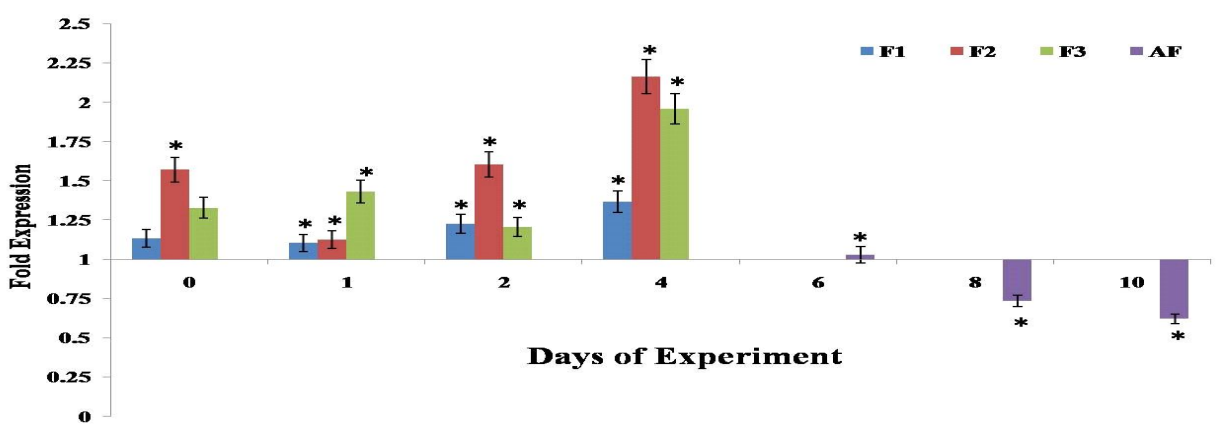

Fig 6: The mRNA expression profile of Survivin gene in hierarchial $\left(F_{1}, F_{2}\right.$ and $\left.F_{3}\right)$ and atretic follicle (AF) of Japanese quail under stress (mean $\pm \mathrm{SEM}, \mathrm{N}=6$ ). ${ }^{*}$ Significant at $P<0.05$.

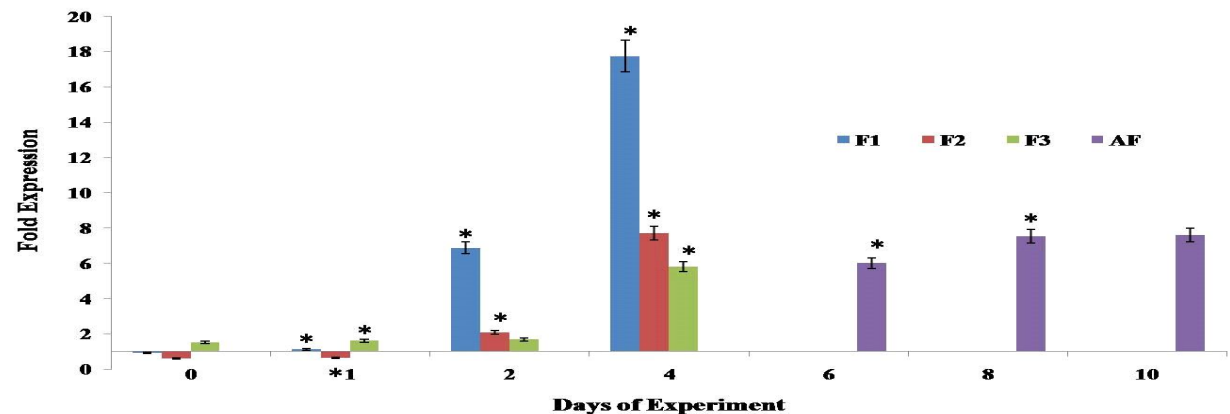

Fig 7: The mRNA expression profile of Caspase-2 gene in hierarchial $\left(F_{1}, F_{2}\right.$ and $\left.F_{3}\right)$ and atretic follicle (AF) of Japanese quail under stress (mean $\pm \mathrm{SEM}, \mathrm{N}=6$ ). ${ }^{*}$ Significant at $P<0.05$. 


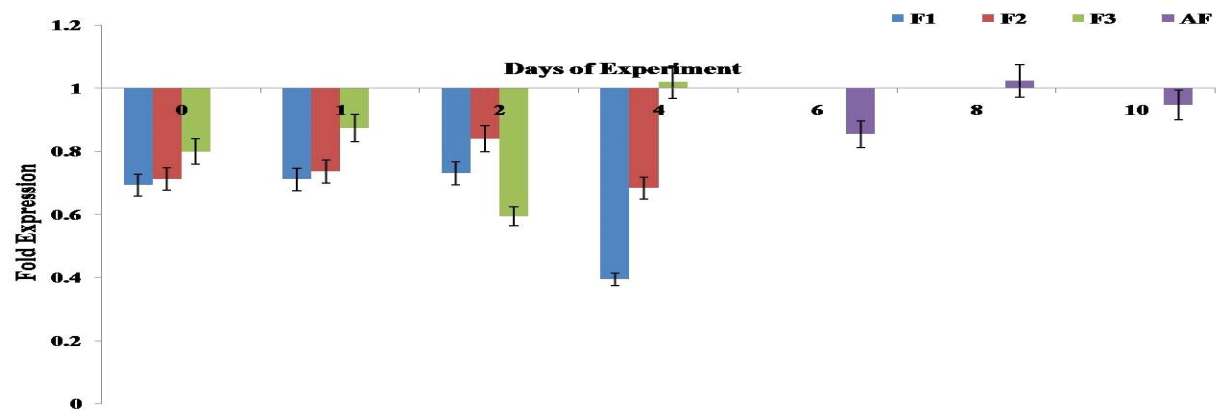

Fig 8: The mRNA expression profile of HSP-70 gene in hierarchial $\left(F_{1}, F_{2}\right.$ and $\left.F_{3}\right)$ and atretic follicle of Japanese quail under stress (mean $\pm \mathrm{SEM}, \mathrm{N}=6$ ). ${ }^{*}$ Significant at $P<0.05$.

in counteracting the negative effect of heat shock on immunocompetence by induction of high intensity of HSP70 transcription (Faisal et al., 2008). Increased expression of HSP-70 was also detailed in the myocardial tissue of Japanese quail exposed to loud noise, inescapable irritation, cold temperature and isolation in darkness (Hoekstra et al., 1998).

\section{CONCLUSION}

The study concludes that stress on feed withdrawal in Japanese quail is enough for reproductive tissue regression. The vibrant changes in the serum level of sex steroids and corticosterone is well correlated with the oviductal regression and follicular atresia. It appears that expression of IGF-1, Survivin, Caspase-2 gene signifies their involvement in the tissue regression via endocrine changes. However, the exact signalling and consequences for reproductive tissue regression in Japanese quail during stress is yet to be established.

\section{ACKNOWLEDGEMENT}

Authors are very much thankful to Dr. R.P. Singh, Director, Central Avian Research Institute and (Mrs.) Mohini Saini, Senior Scientist, Division of Animal Biochemistry, Indian Veterinary Research Institute for their scientific sharing and moral support to carryout and complete the work.

\section{REFERENCES}

Agarwal, R., Sastry, K.V.H., Tripathi, V., Singh, R., Saxena, R., Mohan, J., Singh, R.P. (2013). Expression profile of luteinizing hormone receptor gene in hierarchal follicles and regressing oviduct tissues of White Leghorn hens during moulting. Reproduction in Domestic Animals. 48: 278-283.

Ambrosini, G., Adida, C., Altieri, D.C. (1997). A novel anti-apoptosis gene, Survivin, expressed in cancer and lymphoma. Natural Medicine. 3: 917-921.

Amrutkar, S.A., Leo, J., Jalaludeen, A. (2013). Influence of mating ratio on fertility and hatchability in Japanese quail. Indian Journal of Poultry Science. 48(2): 145-148.

Anish, D., Sastry, K.V.H., Sundaresan, N.R., Saxena, V.K., Singh, R., Mohan, J. (2008). Reproductive tissue regression: involvement of caspases, inducible nitric oxide synthase and nitric oxide during moulting in White Leghorn hens.
Animal Reproduction Science. 104: 329-343.

Bell, D.D. (2003). Historical and current molting practices in the U.S. table egg industry. Poultry Science. 82: 965-970.

Berry, W.D. (2003). The physiology of induced molting. Poultry Science. 82: 971-980.

Brandt, Y., Lundeheim, N., Madej, A., Rodriguez-Martinez, H., Einarsson, S. (2007). Effects of ACTH injections during estrus on concentrations and patterns of progesterone, estradiol, LH, inhibin and time of ovulation in the sow. Domestic Animal Endocrinology. 32: 122-137.

Cockrem, J.F., Adams, D.C., Bennett, E.J., Candy, E.J., Henare, S.J., Hawke, E.J., Potter, M.A. (2004). Endocrinology and the conservation of New Zealand birds. In: Gordon, M.S., Bartol, S.M. (Eds.), Experimental approaches to conservation biology. University of California Press, Los Angeles, pp. 101-121.

El Halawani, M.E., Waibel, P.E., Appel, J.R., Good, A.L. (1973). Effects of temperature stress on catecholamines and corticosterone of male turkeys. American Journal of Physiology. 224: 384-388.

Faisal, B.A., Abdel Fattah, S.A., El Hommosany, Y.M., Abdel Gawad, N.M., Ali, M.F.M. (2008). Immunocompetence, hepatic heat shock protein 70 and physiological responses to feed restriction and heat stress in two body weight lines of Japanese quail. International Journal of Poultry Science. 7(2): 174-183.

Figueiredo, D., Getrle, A., Cabello, G., Decuypere, E., Buyse, J., Dridi, S. (2007). Leptin down regulates heat shock protein-70 (HSP-70) gene expression in chicken liver and hypothalamus. Cell Tissue Research. 329: 91-101.

Gaviol, H.C.T., Gasparino, E., Prioli, A.J., Soares, M.A.M. (2008). Genetic evaluation of the HSP70 protein in the Japanese quail (Coturnix japonica). Genetics and Molecular Research. 7(1): 133-139.

Guo, Y., Srinivasula, S.M., Druilhe, A., Fernandes-Alnemri, T., Alnemri, E.S. (2002). Caspase-2 induces apoptosis by releasing proapoptotic proteins from mitochondria. Journal of Biological Chemistry. 227(16): 13430-13437.

Harvey, S., Phillips, J.G., Rees, A., Hall, T.R. (1984). Serum and adrenal function. Journal of Experimental Zoology. 232: 633.

Heck, A., Metayer, S., Onagbesan, O.M., Williams, J. (2003). mRNA expression of components of the IGF system and of GH and insulin receptors in ovaries of broiler breeder hens fed ad libitum or restricted from 4 to 16 weeks of age. 
Domestic Animal Endocrinology. 25: 287-294.

Hoekstra, K.A., Iwama, G.K., Nichols, C.R., Godin, D.V.,Cheng, K.M. (1998). Increased heat shock protein expression after stress in Japanese quail. Stress. 2(4): 265-72.

Johnson, M.E., Howerth, E.W. (2004). Survivin: A bifunctional inhibitor of apoptosis protein. Veterinary Pathology. 41 : 599-607.

Johnson, A.L., Bridgham, J.T., Swenson, J.A. (2001). Activation of the Akt/protein kinase B signaling pathway is associated with granulosa cell survival. Biology of Reproduction. 64: 1566-1574.

Kiang, J.G., Tsokos, G.C. (1998). Heat shock protein 70 kDa molecular biology, biochemistry and physiology. Pharmacology and Therapeutics. 80: 183-201.

Kobayashi, M., Ito, T., Ishii, S., Wada, M. (2004). Seasonal change in luteinizing hormone subunit mRNA in Japanese quail and effects of short day length and low temperature. General and Comperative Endocrinology. 139: 38-47.

Lovell, T.M., Gladwell, R.T., Groome, N.P., Knight, P.G. (2002). Modulatory effects of gonadotrophins and insulin-like growth factor on the secretion of inhibin A and progesterone by granulose cells from chicken preovulatory (F1-F3) follicles. Reproduction. 123: 291-300.

Melissa, K.T., Daniel, W.C., David, C. andrew, K.G., William, E.G., Karl, E.K., William, R., Martin, S., Lynn, S., Sanford, S., Wendy, W., Dean, E.B. (2009). Standard Operating Procedures for Serum and Plasma Collection: Early Detection Research Network Consensus Statement Standard Operating Procedure Integration Working Group. Journal of Proteome Research. 8(1): 113-117.

Moudgal, R.P., Mohan, J., Panda, J.N. (1990). Effect of prolactin, epinephrine and serotonin on follicular atresia and phosphatise levels in ovarian follicles of hens. Indian Journal of Poultry Science. 25: 37.

Moudgal, R.P., Mohan, J., Panda, J.N. (1991). Immobilization stress mediated priority of adverse action at growing ovarian follicles level and its interaction with summer stress in hens. Indian Journal of Animal Science. 61: 1077-1079.

Paroni, G., Henderson, C., Schneider, C., Brancolini, C. (2001). Caspase-2 induced apoptosis is dependent on caspase9 , but its processing during UV or tumor necrosis factordependent cell death requires caspase-3. Journal of Biological Chemistry. 276 (24): 21907-21915.

Pfaffl, M.W., Graham, W., Horgan, L., Dempfle, L. (2002). Relative expression software tool (RESTC) for group-wise comparison and statistical analysis of relative expression results in real-time PCR. Nucleic Acids Research. 30: 62-66.

Pilo, B., Etches, R.J., George, J.C. (1985). Effects of corticosterone infusion on the lipogenic activity and ultrastructure of the liver of laying hens. Cytobioscience. 44(179S): 273-285.

Razdan, P. (2003). Stress and early pregnancy in sows. Effects on endocrinology, ova transport and embryo development. In Doctoral thesis, Veterinaria 153, Acta Universitatis Agriculturae Sueciae, Swedish University of Agricultural Sciences, Uppsala.

Robinson, J.J., Sinclair, K.D., McEvoy, T.G. (1999). Nutritional effects on foetal growth. Animal Science. 68: 315-331.

Shin, S., Sung, B.J., Cho, Y.S., Kim, H.J., Ha, N.C., Hwang, J.I., Chung, C.W., Jung, Y.K., Oh, B.H. (2001). An anti-apoptotic protein human survivin is a direct inhibitor of caspase-3 and -7. Biochemistry. 40: 1117-1123.

Shit, N., Sastry, K.V.H., Singh, R., Moudgal, R.P. (2014). Effect of stress on the percent body weight change and mRNA expression of IGF-1, survivin and HSP-70 gene in the hierarchial follicles of Japanese quail. Exploratory Animal and Medical Research. 4(2): 172-182.

Shit, N., Sastry, K.V.H., Singh, R.P., Singh, G. (2016). Effect of stress on the oviductal regression and mRNA expression of progesterone and luteinizing hormone receptors in Japanese quail hens. Journal of Poultry Science and Technology. 4(1): 11-18.

Shit, N., Sastry, K.V.H., Singh, R.P., Pandey, N.K., Mohan, J. (2014). Sexual maturation, serum steroid concentrations and mRNA expression of IGF-1, luteinizing and progesterone hormone receptors and survivin gene in Japanese quail hens. Theriogenology. 81: 662-668.

Skarzynski, D.J., Jaroszewski, J.J., Okuda, K. (2005). Role of tumor necrosis factor-alpha and nitric oxide in luteolysis in cattle. Domestic Animal Endocrinology. 29: 340-346.

Sundaresan, N.R., Anish, D., Sastry, K.V.H., Saxena, V.K., Mohan, J., Ahmed, K.A. (2007). Cytokines in reproductive remodeling of molting White Leghorn hens. Journal of Reproductive Immunology. 73: 39-50.

Sundaresan, N.R., Saxena, V.K., Sastry, K.V.H., Nagarajan, K. Jain, Preeti., Singh, Rani., Anish, D., Ravindra, P.V., Saxena, M., Ahmed, K.A. (2008). Cytokines and chemokines in postovulatory follicle regression of domestic chicken (Gallus gallus domesticus). Developmental and Comperative Immunology. 32: 253-264.

Tamm, I., Wang, Y., Sausville, E., Scudiero, D. A., Vigna, N., Oltersdorf, T., Reed, J. C. (1998). IAP-family protein survivin inhibits caspaseactivity and apoptosis induced by Fas (CD95), Bax, caspases and anticancer drugs. Cancer Research. 58: 5315-5320.

Tosca, L., Chabrolle, C., Crochet, S., Tesseraud, S., Dupont, J. (2008). IGF-1 receptor signaling pathway and effects of AMPK activation on IGF-1-induced progesterone secretion in hen granulosa cells. Domestic Animal Endocrinology. 34: 204-16.

Wheatley, S.P., McNeish, I.A. (2005). Survivin: a protein with dual roles in mitosis and apoptosis. International Review of Cytology. 247: 35-88. 